\title{
Microeconomic and Macroeconomic Determinants of Efficiency: Evidence from Indian Manufacturing Sub-Sectors
}

\author{
Sumit Kumar Maji ${ }^{\mathrm{a}}$, Arindam Laha ${ }^{\mathrm{a}}$, Debasish Sur ${ }^{\mathrm{a}}$ \\ ${ }^{a}$ Department of Commerce, The University of Burdwan, India
}

\begin{abstract}
In this paper an effort was made to evaluate the level of efficiency of the firms that belong to the selected manufacturing sub-sectors in India for the period 1999-2000 to 20132014 using Stochastic Frontier Analysis. Subsequently, the microeconomic and macroeconomic determinants of efficiency were analysed applying Panel Censored Tobit Regression Model. The study revealed that Electrical Equipment sub-sector was found to be the most efficient sector followed by the sub-sectors Auto Parts and Equipment, Pharmaceutical and Biotechnology, Chemicals, Textile, Food products and Steel respectively. The study also showed that leverage, size of the firm, age of the firm, openness of the firm (microeconomic) and inflation (macroeconomic) made notable contribution towards changing the level of efficiency of manufacturing firms during the study period. However, their contributions were not the same in all sub-sectors under study.

Keywords: Efficiency, Manufacturing Sub-sectors, Stochastic Frontier Analysis

Received:

27 November 2019

Accepted revised version:

13 March 2020

Published:

30 June 2020

Suggested citation: Maji, S. K., Laha, A., \& Sur, D. (2020). Microeconomic and macroeconomic determinants of efficiency: Evidence from Indian manufacturing subsectors. Colombo Business Journal. 11(1), 47-82.

DOI: http://doi.org/10.4038/cbj.v11i1.57

(C)2020 The Authors. This work is licenced under a Creative Commons Attribution 4.0 International Licence which permits unrestricted use, distribution, and reproduction in any medium, provided the original work is properly cited.
\end{abstract}

『2009sumitbu@gmail.com: iD https://orcid.org/0000-0001-7592-6594 


\section{Introduction}

The Indian economy, especially the manufacturing sector has gone through many phases of transformation since independence. With a view to establish a 'socialistic pattern in the society', it was believed that large scale public sector organisations should assume greater responsibility. The aims were to ensure balanced regional development, fostering economic growth and creation of a large number of employment opportunities. The attainment of these goals could only be ensured by having a strong manufacturing sector in the economy. It can never be denied that the manufacturing sector is quintessential for sustainable economic growth and higher standard of living in any economy (Felipe et al, 2018; Haraguchi et al., 2017). This argument is not a new one; it was empirically well established by Kaldor way back in 1967 where he showed the interconnectedness between the productivity of the manufacturing sector and economic growth.

In the context of India, only after the implementation of the pro-market economic policies in late 1980s and early 1990s, a favourable business environment was created where the industries could grow (Kochhar et al., 2006). It was empirically established that the reduction of tariffs, withdrawal of industrial licensing, deregulation, removal of restrictions on imports and exports due to the economic reform measures promoted efficiency (Kathuria et al., 2012). With the gradual opening up of the Indian economy since mid-eighties, the opportunity for growth for manufacturing firms has multiplied on one hand and on the other hand firms have been facing externalities emanating from the exposure to the industry specific and macroeconomic factors which were not so powerful prior to the opening up of the economy as a whole. In a liberalised economic environment, the competition becomes fierce (Kambhampati \& Parikh, 2005). In the wake of such a highly competitive environment, firms that belong to the Indian manufacturing sector have to operate efficiently in order to sustain in the long run. Therefore, it is of utmost importance to understand the diversified factors which are capable of affecting the level of efficiency of the firms especially in the post-liberalisation regime.

The various factors which affect a firm normally get classified into three broad categories such as microeconomic, industry specific and macroeconomic factors (Sufian, 2009). Irrespective of the policy regime, these three factors have remained at the core of the efficiency vis-a-vis financial performance of firms that belong to each and every sector of the economy including manufacturing. But with the 
opening up of the economy, the industry and macroeconomic factors have become even more important (Majumdar \& Bhattacharjee, 2010). Thus, the formulation of business strategies in a post-liberalised business environment requires special consideration of all these three factors together. Afterwards with the passage of time, Indian industries started growing and such a growth along with reasonably good returns attracted many other new entrants into the market economy leading to an extremely high degree of competition. Therefore, in the present age of cut throat competition, it is inevitable to manage the business with the highest degree of efficiency to survive in the long run.

The level of competition between firms that belong to the Indian manufacturing sector is very high as evidenced by the existence of a large number of firms in each and every manufacturing segment. With the emergence of the liberalisation measures in India in 1991, such competition has been more intensified ${ }^{1}$. Effective utilisation of the available scarce resources is of utmost important for achieving corporate excellence. Effective usage of the available human capital, technology, scale and managerial potential has direct impact on the cost effectiveness, profitability and ultimately on the market value of the firms. Perhaps this is one of the prime reasons for which many research scholars have delved into the exploration of the level of efficiency of firms. In a perfectly competitive and liberalised economy where prices of the factors of production are market determined, the only way to sustain is to attain the optimum level of efficiency. Openness of the economy leading to an increased competition ensures that the resources are put to optimum use (Driffield \& Kambhampati, 2003).

The scholars have not restricted their effort in enquiring into the level of efficiency of firms that belong to different sectors; rather they have also tried to illuminate the underlying factors responsible for such level of efficiency or otherwise. In case of manufacturing firms it has been noted that there exists a close nexus between the size of the firms and the level of efficiency. Large size firms enjoying economies of scale (Alvarez \& Crespi 2003) are expected to be more efficient than the small size firms (Firth et al., 2015; Halkos \& Tzeremes, 2007; Kalaitzandonakes et al., 1992; Lundvall \& Battese, 2000; Pitt \& Lee, 1981; Söderbom \& Teal, 2004;). However, recent studies show that if the large size firms are suffering from debt overhang problems then these firms become less efficient

\footnotetext{
${ }^{1}$ As of 31/05/2019 there were 233,412 (20\% of the total) registered active manufacturing companies in India (MCA, 2019) retrieved from http://www.mca.gov.in/Ministry/pdf/MIB_May_01072019.pdf
} 
than the small size firms (Hanousek et al., 2015). In addition to that it has been noted that the efficiency of the small size firms are conditioned upon the age of the firms, level of technological upgrading, geographical location, government assistance, innovation capability, Research and Development (R\&D) intensity, experience of the workforce, foreign collaboration, female participation in the workforce, export orientation, education of the owner, subcontracting possibility, conglomeration strategy and financial integration (Ahmed \& Ahmed, 2013; Alvarez \& Crespi, 2003; Burki \& Terrell, 1998; Harvie, 2004; Hall et al., 2009; Hill \& Kalirajan, 1993; Le \& Harvie, 2010; Pelham, 2000; Weston \& Mansinghka, 1971;J. C. Yang, 2006; C. H. Yang \& Chen, 2009). However in the prelude of India, Kambhampati and Parikh (2005) suggested that small firms could not exploit advantages stemmed from the liberalisation measures contrary to the experience in other countries of the world.

Under the Indian scenario, Bhavani (1991) indicated the existence of a high level of efficiency in the Indian metal industry during the time period of 1973-1974. In contrast, Neogi and Ghosh (1994) suggested the decline in the efficiency of the manufacturing firms and the existence of variability across different manufacturing industries during 1974-1975 to 1987-1988. Driffield and Kambhampati (2003), Kumar (2006), Madheswaran et al. (2007) and Pattnayak and Thangavelu (2005) suggested that the level of efficiency of Indian manufacturing industries improved in the post-reform era as compared to that of the pre-reform period which was also supported by the outcome of the study conducted by Mitra (1999). In fact, Total Factor Productivity Growth has improved during 1985-1986 to 1992-1993 when compared to the period during 1976-1977. On the contrary, Mukherjee and Ray (2005) demonstrated, using the state level data on Indian manufacturing, that the rankings of the different states in terms of the efficiency of the manufacturing sector did not change dramatically before and after the liberalisation measures undertaken in 1991. However, these findings were again contradicted by a study carried out by Kumar (2006) which indicated that the total factor productivity started converging across different regions after liberalisation. The study conducted by Ferrantino (1992) in respect of the Indian manufacturing sector revealed that purchase of technology had failed to bring any improvement in the efficiency of firms rather the direction of the use of the technology had positive implication on the efficiency. In a state level analysis Mitra et al. (2002) showed that availability of infrastructure was one of the prime reasons of the variability of the productivity growth and technical efficiency amongst the manufacturing industries across different states of India. Similar findings were observed again by Mitra et al. $(2011,2012)$ on eight 
core manufacturing industries for the period between 1994-2008 and suggesting that the persistence of the lack of information, communication and technology and infrastructure in India had affected the efficiency of the firms. In a similar vein, Sharma and Sehgal (2010) observed improvement in the efficiency of the Indian manufacturing sector during 1994-2006 and identified availability of infrastructure to be the most significant variable affecting such efficiency. In an effort to determine the efficiency of the Indian engineering industry, Golder and Kumari (2003) noted that foreign engineering firms were more efficient than their domestic counterparts. The study also suggested that the efficiency of the foreign and domestic engineering firms operating in India would eventually converge. Similarly, sugar manufacturing companies in India were found to be efficient (Dwivedi \& Ghosh, 2014).

In a very recent study in the context of Indian glass industry Kundi and Sharma (2016) suggested that more or less all firms were found to be efficient but small size foreign controlled, experienced firms were found to be comparatively more efficient than the other firms, which is again contradictory to the findings of the study carried out by Alvarez and Crespi (2003). Again in a different study Kundi and Sharma (2016) found the large scale Cement companies especially foreign controlled ones operating in India to be more efficient when compared to their small and medium scale counterparts. In the context of Indian textile firms, the study conducted by Bhandari and Maiti (2007) found that size, age and ownership of firms were the major factors affecting the efficiency of those firms. Gambhir and Sharma (2015) also obtained similar findings in case of the textile companies in India and in addition to that they have also observed that export oriented Indian textile firms were always better off. The underlying rationale may be that only the efficient firms engage in foreign trade and in order to become export competitive, they have to run their organisations more efficiently than other non-exporting firms (Van Biesebroeck, 2005). In line with this argument, Bigsten et al. (2004) and Van Biesebroeck (2005) observed that African and Sub-Saharan manufacturing firms engaged in international exports were relatively more efficient.

In the context of manufacturing companies in the state of Haryana, India, Sharma and Sehgal (2015) found a positive association between the levels of productivity and profitability and emphasized on the role of innovation for the optimum utilisation of resources. Hasan (2002) and Basu and Das (2015) suggested that in medium and short run, use of technology is the most important determinant of corporate profitability and efficiency in the Indian organized manufacturing 
sector. Some of the other important factors identified by different research studies were size of the firm, age of the firm, ownership structure, number of employees, profitability, prevalence of competition, liberalisation, exports, labour cost, foreign ownership, capitalisation, subsidies, management costs, education of the owners, quality of human capital, , R \& D, innovation, existence of crimes and political risk, infrastructure, product diversification and international diversification, use of technology, managerial efficiency, remuneration of the top management and workers, market to book value ratio, financial leverage, early adoption of technology, governance quality, government grants and assistance, rate of taxes, foreign investment and training cost of employees (Baek \& Neymotin, 2016; Blomström, 1986; Biener et al., 2016; Castiglione \& Infante, 2014; Chapelle \& Plane, 2005; Chuang \& Lin, 1999; Diaz-Balteiro et al., 2006; Doaei et al., 2015; Firth et al., 2015; Forlani, 2012; Giokas et al., 2015; Hanousek et al. ,2015; Ismail \& Sulaiman, 2007; Jain et al., 2015; Kumbhakar et al., 1991; O'Toole and Tarp, 2014; Piesse \& Thirtle, 2000; Pitt \& Lee, 1981; Thatcher \& Oliver, 2001; Weill, 1992; Yu et al., 2012; Zhang et al, 2003; Zheng et al., 1998). Amongst all factors, ownership (i.e. whether government or private, domestic or foreign firm) dictates the efficiencies of firms to a great extent (Blomström, 1986; McConaughy et al., 1998; Vining \& Boardman, 1992). Other significant determinants of the efficiency of manufacturing firms are good corporate governance, (Gill \& Biger, 2013) marketing facilities and infrastructure provided by the government (Cull et al., 2017).

Efficiency analysis is of great importance to managers of corporate firms in order to identify weaknesses and strengths associated with their firms that enable them to adopt appropriate managerial decisions and strategies so as to achieve the objective of the wealth maximisation and optimum utilisation of the available resources (Kundi \& Sharma, 2016). The efficient firms are expected to possess the inherent capacity to cope up with the dynamic macroeconomic environment and enjoy greater sustainability. Review of the existing literature suggests that there is scant number of studies that have tried to explore the effect of both the microeconomic and macroeconomic factors simultaneously on the firm level efficiency of Indian manufacturing firms in a comprehensive manner.

In this backdrop, the present study has made a modest attempt to unearth the level of efficiency of firms that belong to the various sub-sectors of the Indian manufacturing industry. In addition to this specific objective, efforts have also been made to evaluate the microeconomic as well as macroeconomic determinants of such efficiency. 


\section{Data Sources and Methodology}

\section{Data Sources}

For the purpose of analysing the determinants of the firm level efficiency of Indian manufacturing firms, the firm level data for the period of study from 19992000 to 2013-2014 were collected from the Capitaline Corporate Database published by Capital Market Publishers Private Ltd. Mumbai, India ${ }^{2}$. Although the time period of the study could have been extended to the current period, different companies that belong to the Indian manufacturing industry had already adopted Ind-AS and started reporting using the Ind-AS guidelines which were converged with International Financial Reporting Standards from 2014-2015. Such an extension of the period of study could have created a non-compatibility issue between financial information produced as per erstwhile Accounting Standards issued by the Accounting Standards Board of India and Ind-AS issued by the Ministry of Corporate Affairs, Government of India. Therefore, it was thought to be prudent to keep the period of study from 1999-2000 to 2013-2014. The macroeconomic data relating to exchange rate and inflation for the same period were taken from the Database on Indian Economy, $\mathrm{RBI}^{3}$.

Table 1: Data Sources and Period of the Variables Used in the Study

\begin{tabular}{|c|c|c|}
\hline Variables & Source & Period \\
\hline $\begin{array}{l}\text { Raw Material Cost, Employee Cost, } \\
\text { Power and Fuel Cost, Gross block } \\
\text { of Asset, Value of Output, } \\
\text { Leverage, Age, Size, Growth, } \\
\text { Openness }\end{array}$ & $\begin{array}{l}\text { Capitaline Corporate Database } \\
\text { published by Capital Market } \\
\text { Publishers Private Ltd. Mumbai, } \\
\text { India }\end{array}$ & $\begin{array}{l}1999-2000 \\
\text { to }\end{array}$ \\
\hline $\begin{array}{l}\text { Real Effective Exchange Rate } \\
\text { (REER), Wholesale Price Index } \\
\text { (WPI) }\end{array}$ & $\begin{array}{l}\text { Database on Indian Economy, } \\
\text { Reserve Bank of India (RBI) }\end{array}$ & 2013-2014 \\
\hline
\end{tabular}

\section{Methodology}

\section{Selection of Sample Firms}

In the present study only the Indian manufacturing sector as per National Industry Classification, $2008^{4}$ was concentrated upon. Although the service sector is growing rapidly, the remarkable contribution of the manufacturing sector to the

\footnotetext{
${ }^{2}$ https://www.capitaline.com

${ }_{3}^{3}$ https://dbie.rbi.org.in/DBIE/dbie.rbi?site=publications

4 http://mospi.nic.in/sites/default/files/6ec_dirEst/ec6_nic_2008_code.html
} 
economic growth and employment generation cannot be undermined (Rajan, 2006) since manufacturing is considered to be dominant in the industry sector. The other prominent reason for the selection of the manufacturing industry is that, in the Index of Industrial Production (IIP) calculation, manufacturing sectors retain the maximum weight $(75.53 \%)$ over mining (14.16\%) and electricity (10.32\%) (Government of India, 2013). In order to perform the firm level analysis, the list of the different sectors within the broad Indian manufacturing industry, Bombay Stock Exchange (BSE) - Manufacturing index ${ }^{5}$ obtained from the official website of Asia Index Private Limited ${ }^{6}$ was used. At first, BSE-Sectors were selected purposively;

Table 2: Sample Companies across Different Sectors in the Indian Manufacturing Industry

\begin{tabular}{lllll}
\hline BSE Sector & $\begin{array}{l}\text { BSE Industry } \\
\text { Group }\end{array}$ & $\begin{array}{l}\text { BSE Industry Sub- } \\
\text { Group }\end{array}$ & $\begin{array}{l}\text { Population } \\
\text { Size }^{\mathbf{a}}\end{array}$ & $\begin{array}{l}\text { Sample } \\
\text { Size }\end{array}$ \\
\hline Basic Materials & Steel & $\begin{array}{l}\text { Iron \& Steel and } \\
\text { Intermediary }\end{array}$ & $\begin{array}{l}108 \\
(10.95 \%)\end{array}$ & $\begin{array}{l}45 \\
(11.17 \%)\end{array}$ \\
& Chemical & $\begin{array}{l}\text { Products } \\
\text { Commodity and } \\
\text { Specialty Chemical }\end{array}$ & $\begin{array}{l}183 \\
(18.56 \%)\end{array}$ & $\begin{array}{l}80 \\
(19.85 \%)\end{array}$ \\
Consumer & Textiles, Apparels & Textile & 280 & 99 \\
$\begin{array}{l}\text { Discretionary } \\
\text { Goods and }\end{array}$ & and Accessories & & $(28.40 \%)$ & $(24.57 \%)$ \\
Services & Auto Components & Auto Parts and & 101 & 48 \\
& & Equipment & $(10.24 \%)$ & $(11.91 \%)$ \\
Health Care & Pharmaceuticals and & Pharmaceuticals and & 165 & 68 \\
& Biotechnology & Biotechnology & $(16.73 \%)$ & $(16.87 \%)$ \\
Industrials & Electrical & Heavy and Other & 88 & 38 \\
& Equipment & Electrical & $(8.92 \%)$ & $(9.43 \%)$ \\
& & $\begin{array}{l}\text { Equipment and } \\
\text { products }\end{array}$ & & \\
Fast Moving & Food Products & Packaged and Other & 61 & 25 \\
Consumer Goods & & Food Products & $(6.19 \%)$ & $(6.20 \%)$ \\
Total & & & 986 & 403 \\
& & & $(100 \%)$ & $(100 \%)$ \\
\hline
\end{tabular}

Note: ${ }^{a}$ The population size is based on the list of the listed companies under different Industry SubGroup as of 09/02/2016 as downloaded from BSE website.

\footnotetext{
${ }^{5}$ http://www.asiaindex.co.in/indices/equity/sp-bse-india-manufacturing-index\# ; https://us.spindices.com/documents/methodologies/methodology-sp-bse-thematic-indices.pdf

${ }^{6}$ Asia Index Pvt. Ltd is a partnership between S\&P Dow Jones Indices LLC and Bombay Stock Exchange Ltd.
} 
thereafter BSE-Industry group and sub-group were also chosen purposively from the Bombay Stock Exchange (BSE) - Manufacturing index ${ }^{7}$ construction methodology. Once the industry subgroups were selected, the lists of the firms from different sub groups were collected from the official website ${ }^{8}$ of BSE, Mumbai, India. Finally, random sampling technique was used to select the companies to avoid any form of selection bias. Proportional sampling method was used in selecting representative samples by making the selection proportionately from each of the sub-groups. Inclusion criteria at the firm level were, the availability of the firm-specific data for the period of 15 years from 1999-2000 to 2013-2014. However, considering the number of the firms which were finally available as per the inclusion criteria, the proportion of the sample in each of the industry subgroups could not be strictly maintained. Still, the spirit of the proportional sampling method could be retained while determining the final number of the firms from each industry sub-groups. A total number of 403 (40.87\%) companies were finally considered for the final analysis. Table 2 shows the selection process of the sample companies and the sectoral indices for the purpose of the study.

\section{Measurement of Efficiency and its Determinants}

Technical efficiency can be measured by applying two distinct approaches: Data Envelopment Analysis (DEA) as introduced by Charnes et al. (1978) and Stochastic Frontier Analysis (SFA) as propounded by Aigner et al. (1977). DEA is a non-parametric approach based on mathematical programming estimation, while SFA is a parametric approach based on econometric estimation. Both the approaches have advantages and limitations. One of the major advantages of DEA is that it does not require any functional form specification of production function (Hjalmarsson et al., 1996). However, this method suffers from the drawback that it is deterministic in nature and assumes that deviation of firms from the efficient frontier are only due to inefficiencies, which is a very restrictive assumption. On the contrary, under SFA, stochastic noise term is considered which means that the deviations of firms from the efficient frontier are not only attributed to inefficiencies but also to stochastic noise (Din et al., 2007). In addition, the method also allows for the statistical testing of hypotheses relating to the production function and degree of inefficiency. It is also to be kept in mind a priori specification of the functional form of production function is required to be made under SFA which can be considered as a major drawback of this approach. Although two approaches are extensively

\footnotetext{
${ }^{7}$ http://www.asiaindex.co.in/indices/equity/sp-bse-india-manufacturing-index\# ; https://us.spindices.com/documents/methodologies/methodology-sp-bse-thematic-indices.pdf ${ }^{8}$ https://www.bseindia.com/corporates/List_Scrips.aspx?expandable $=1$
} 
used in the existing literature, the application of any of these two is surely going to depend upon various contextual factors (Banker et al., 1993). Din et al. (2007) suggested that the application of DEA will be more suitable when the production function follows the neo-classical theory and there is no measurement error whereas if measurement error is a strong possibility, then SFA will surface itself to be a better method. Without going into such a methodological debate, many researchers have applied and compared DEA with SFA (Cullinane et al., 2006; Din et al., 2007; Hossain et al., 2012; Nazarko \& Chodakowska, 2017; Theodoridis \& Psychoudakis, 2008).

For the purpose of this study, initially DEA approach was used in a panel data framework. However, the outcome of the DEA failed to capture the variation in the efficiency of firms across industries and time periods. Moreover, there was no difference in the total factor productivity growth over time periods for the various Indian manufacturing sub-sectors (Maji, 2019). The Malmquist Total Factor Productivity Growth decomposition clearly showed almost no change in terms of Malmquist Total Factor Productivity Change, Technological Change, Technical Efficiency Change, Pure Technical Efficiency Change and the Scale Efficiency Change. It precisely indicates the failure of the DEA approach to capture the interfirm and intra-firm variation in efficiency (Maji, 2019). Such inability of DEA method to capture any variation of efficiency amongst the firms speaks about the inherent limitations of the method especially in a panel data framework. However, the analysis based on SFA performed well in capturing the variation in the efficiency of firms under manufacturing sub-sectors over the period of study. It shows that the SFA is more suitable in this case as compared to DEA and it also confirms that the variation in efficiency in firms were not only due to inefficiencies but also due to stochastic noise. Therefore, it was thought prudent to proceed with SFA rather than DEA. Moreover, Hjalmarsson et al. (1996) argues that in a panel data framework SFA offers better production function specification which conforms to our empirical findings.

While attaining the objectives of the study, a two-stage approach was considered. The first stage involves the estimation of a stochastic frontier production function by Maximum Likelihood Estimation and the predicted values of firm-level technical efficiency scores. Stochastic frontier production function and the predicted firm-level technical efficiencies were estimated using the computer program, Frontier Version 4.1 (Coelli, 1996). In the second stage these predicted technical efficiency effects were regressed on firm-specific and macroeconomic 
factors in order to determine factors influencing the efficiency. In the second stage Panel Censored Tobit regression model was used to illuminate the determinants of such efficiency. The detailed descriptions of the variables used in the study are presented in Table 3.

Table 3: Descriptions of Variables

\begin{tabular}{llll}
\hline & & Variables & \multicolumn{1}{c}{ Descriptions } \\
\hline & & Raw Material Cost (RMC) & Natural logarithm of Raw Material \\
& & Employee Cost (EC) & Natural logarithm of Employee Cost \\
& & Power and Fuel Cost (PFC) & Natural logarithm of Power and Fuel \\
Cost
\end{tabular}

Notes: aFrom Hitt et al. (1997)

${ }^{b} \mathrm{WPI}$ is the better measure of inflation in the industrial performance evaluation context when compared with the Consumer Price Index (CPI). WPI reflects the level of price at which goods and services are exchanged between firms within and between different industries (Mishra, 2013).

For the purpose of determining the technical efficiency of the manufacturing firms, Stochastic Frontier Analysis (Coelli, 1996) was applied in the first stage 
under the panel data framework. Specific stochastic frontier production function model which was estimated is:

$$
\ln \left(O_{i t}\right)=\beta_{0}+\beta_{1} \ln \left(G B A_{i t}\right)+\beta_{2}\left(R M C_{i t}\right)+\beta_{3}\left(P F C_{i t}\right)+\beta_{4}(E C)+\left(V_{i t}-U_{i t}\right)
$$

where $V$ represents random error which is associated with random factors outside the control of the firm, and $U$ represents one sided inefficiency component. Maximum Likelihood Estimates of the parameters of the model can be obtained together with the variance parameters expressed as $\sigma^{2}=\sigma_{u}^{2}+\sigma_{v}^{2}$ and $\gamma=\frac{\sigma_{u}^{2}}{\sigma_{u}^{2}+\sigma_{v}^{2}}$. The parameter $\gamma$ has a value between zero and one, such that the value of zero is associated with traditional response function. The model also estimates the value of $\mu$ which is the inefficiency in the model and $\eta$ representing the change of inefficiency of firms over the time.

Technical efficiency of a firm at a given period of time is defined as the ratio of the observed output to the frontier output which could be produced by a fully efficient firm, in which the inefficiency effect is zero. Thus, technical efficiency is defined as

$$
\text { Efficiency }_{i}=\frac{Y_{i}}{f(x ; \beta)}=\frac{f(x ; \beta) e^{-u_{i}}}{f(x ; \beta)}=e^{-u_{i}}
$$

In order to assess the effect of different firm-specific and macroeconomic factors on the technical efficiency Panel Censored Tobit Regression Model was applied in the second stage. The motivation for using Panel Censored Tobit Regression Model is that the value of the dependent variable, efficiency, varies between 0 and 1 , and other models are incompetent to account for the censored and limiting value of the dependent variable. The econometric specification of the empirical model used in the study is as follows.

$$
\begin{aligned}
\text { Efficiency }_{i t}= & \lambda_{0}+\lambda_{1}(\text { Leverage })_{i t}+\lambda_{2}(\text { Growth })_{i t}+\lambda_{3}(\text { Size })_{i t}+\lambda_{4}(\text { Age })_{i t} \\
& +\lambda_{5}(\text { Openness })_{i t}+\lambda_{6}(\text { Exchnage Rate })_{i t}+\lambda_{7}(\text { Inflation })_{i t} \\
& +\varepsilon_{i t}
\end{aligned}
$$

where $\lambda_{i} \mathrm{~s}$ are the parameters to be estimated, firm and time are denoted by $i$ and $t$ respectively, $i=1,2, \ldots \ldots \ldots \ldots . . . . .2$ and time $t=1,2, \ldots$. 
The expected signs for variables determining the sources of technical efficiency are summarised in Table 4.

Table 4: Expected Sign of the Determinants in Technical Efficiency Model

\begin{tabular}{lcc}
\hline Variables & Parameter & Expected sign \\
\hline Leverage & $\lambda_{1}$ & + \\
Growth & $\lambda_{2}$ & + \\
Size & $\lambda_{3}$ & + \\
Age & $\lambda_{4}$ & + \\
Openness & $\lambda_{5}$ & $+/-$ \\
Exchange Rate & $\lambda_{6}$ & $+/-$ \\
Inflation & $\lambda_{7}$ & $+/-$ \\
\hline
\end{tabular}

Expected signs in Table 4 represent the underlying hypotheses (as formulated from the insights of the existing literature). It is very important to examine whether the results of the empirical estimation correspond with the expected sign of the parameter or not, especially in the context of the different sectors of the manufacturing industry. It is expected that the effects of the different variables on the firm level technical efficiency are different across sectors due to their inherent nature.

\section{Results and Discussion}

\section{Estimation of Production Function}

The coefficients of the estimated production function are presented in Table 5. The analysis made in Table 5 shows that all the coefficients $\left(\beta_{1}\right.$ to $\left.\beta_{4}\right)$ were positive and also found to be statistically significant at $1 \%$ in many sectors in the manufacturing industry. An exception was also noticed in respect of the sign of the coefficient of gross block of assets in food product sub-sector. Positive and statistically significant coefficients associated with the inputs of all the sectors imply that the firms that belong to different sectors within the manufacturing industry were able to utilise the available inputs such as raw material, labour, power and fuel and assets effectively to generate the value of output. Negative value of the coefficients of gross block of assets for Food product sector signifies that these inputs were not used efficiently by the firms in this sector. 
Table 5: Estimation of the Production Functions of Different Manufacturing Sub-Sectors

\begin{tabular}{|c|c|c|c|c|c|c|c|}
\hline 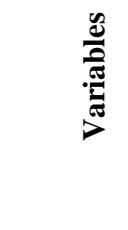 & 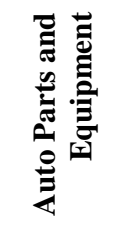 & 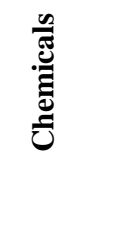 & 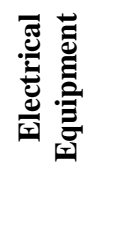 & 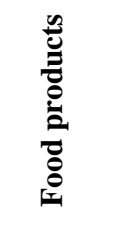 & 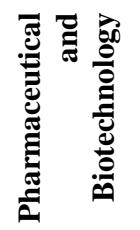 & 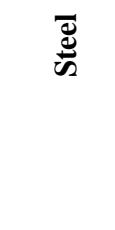 & 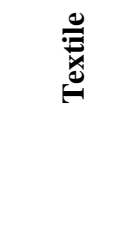 \\
\hline $\begin{array}{l}\text { Constant } \\
\left(\beta_{0}\right)\end{array}$ & $\begin{array}{r}2.17^{* *} \\
(16.77)\end{array}$ & $\begin{array}{r}0.16^{* * *} \\
(3.211)\end{array}$ & $\begin{array}{c}0.91^{*} \\
(2.35)\end{array}$ & $\begin{array}{l}3.35^{* *} \\
(3.48)\end{array}$ & $\begin{array}{l}1.18^{* *} \\
(7.51)\end{array}$ & $\begin{array}{l}3.49^{* *} \\
(9.66)\end{array}$ & $\begin{array}{r}3.23^{* *} \\
(21.26)\end{array}$ \\
\hline $\begin{array}{l}\text { GBA } \\
\left(\beta_{1}\right)\end{array}$ & $\begin{array}{l}0.06^{* * *} \\
(5.22)\end{array}$ & $\begin{array}{r}0.42^{* *} \\
(18.54)\end{array}$ & $\begin{array}{r}0.01 \\
(1.47)\end{array}$ & $\begin{array}{l}-0.93^{* *} \\
(-7.67)\end{array}$ & $\begin{array}{r}0.60^{* * *} \\
(19.13)\end{array}$ & $\begin{array}{r}0.02 \\
(0.41)\end{array}$ & $\begin{array}{c}0.39^{\text {** }} \\
(29.71)\end{array}$ \\
\hline $\begin{array}{l}\mathrm{RMC} \\
\left(\beta_{2}\right)\end{array}$ & $\begin{array}{r}0.73^{* *} \\
(88.66)\end{array}$ & $\begin{array}{r}0.34^{* * *} \\
(26.89)\end{array}$ & $\begin{array}{r}0.84^{* *} \\
(26.37)\end{array}$ & $\begin{array}{r}0.06 \\
(1.61)\end{array}$ & $\begin{array}{c}0.02^{*} \\
(2.12)\end{array}$ & $\begin{array}{r}0.35^{\text {*** }} \\
(19.04)\end{array}$ & $\begin{array}{c}0.22^{\text {** }} \\
(25.42)\end{array}$ \\
\hline $\begin{array}{r}\mathrm{PFC} \\
\left(\beta_{3}\right)\end{array}$ & $\begin{array}{l}0.04^{* *} \\
(4.57)\end{array}$ & $\begin{array}{l}0.04^{* *} \\
(3.68)\end{array}$ & $\begin{array}{r}0.00 \\
(0.07)\end{array}$ & $\begin{array}{r}0.98^{* * *} \\
(12.77)\end{array}$ & $\begin{array}{c}0.02^{*} \\
(2.06)\end{array}$ & $\begin{array}{c}0.32^{* * *} \\
(12.70)\end{array}$ & $\begin{array}{l}0.06^{* *} \\
(7.58)\end{array}$ \\
\hline $\begin{array}{l}\mathrm{EC} \\
\left(\beta_{4}\right)\end{array}$ & $\begin{array}{c}0.13^{* *} \\
(14.30)\end{array}$ & $\begin{array}{r}0.23^{* *} \\
(12.19)\end{array}$ & $\begin{array}{c}0.09^{*} \\
(2.26)\end{array}$ & $\begin{array}{l}1.11^{* *} \\
(8.03)\end{array}$ & $\begin{array}{r}0.37^{* * *} \\
(11.26)\end{array}$ & $\begin{array}{l}0.38^{* *} \\
(6.98)\end{array}$ & $\begin{array}{c}0.29^{* *} \\
(21.60)\end{array}$ \\
\hline$\gamma$ & $\begin{array}{r}0.75^{* *} \\
(44.71)\end{array}$ & $\begin{array}{l}0.31^{* *} \\
(5.07)\end{array}$ & $\begin{array}{r}0.83^{* *} \\
(27.51)\end{array}$ & $\begin{array}{l}0.44^{* *} \\
(4.07)\end{array}$ & $\begin{array}{r}0.84^{* *} \\
(13.03)\end{array}$ & $\begin{array}{c}0.56^{* * *} \\
(12.16)\end{array}$ & $\begin{array}{r}0.53^{* *} \\
\left(20.77^{*}\right)\end{array}$ \\
\hline$\sigma^{2}$ & $\begin{array}{c}0.02^{* * *} \\
(10.26)\end{array}$ & $\begin{array}{l}0.52^{* *} \\
(7.97)\end{array}$ & $\begin{array}{l}2.58^{\text {*** }} \\
(6.03)\end{array}$ & $\begin{array}{l}2.26^{* *} \\
(5.49)\end{array}$ & $\begin{array}{l}1.40^{\text {*** }} \\
(2.47)\end{array}$ & $\begin{array}{l}1.96^{* *} \\
(8.62)\end{array}$ & $\begin{array}{r}0.51^{\text {** }} \\
(13.85)\end{array}$ \\
\hline$\mu$ & $\begin{array}{l}0.25^{\text {** }} \\
(8.42)\end{array}$ & $\begin{array}{l}0.81^{\text {** }} \\
(5.83)\end{array}$ & $\begin{array}{l}-2.93^{* *} \\
(-4.57)\end{array}$ & $\begin{array}{l}1.99^{* *} \\
(3.54)\end{array}$ & $\begin{array}{r}0.43 \\
(0.75)\end{array}$ & $\begin{array}{l}2.10^{* *} \\
(5.37)\end{array}$ & $\begin{array}{c}1.04^{* *} \\
(11.66)\end{array}$ \\
\hline$\eta$ & $\begin{array}{r}0.00 \\
(0.32)\end{array}$ & $\begin{array}{r}0.01 \\
(1.07)\end{array}$ & $\begin{array}{l}-0.30^{* *} \\
(-6.74)\end{array}$ & $\begin{array}{l}-0.02^{* *} \\
(-2.53)\end{array}$ & $\begin{array}{l}-0.02^{* *} \\
(-6.49)\end{array}$ & $\begin{array}{r}0.00 \\
(0.10)\end{array}$ & $\begin{array}{r}0.00 \\
(0.08)\end{array}$ \\
\hline$N$ & 720 & 1200 & 494 & 375 & 1020 & 675 & 1485 \\
\hline
\end{tabular}

Note: Values in parentheses indicate t-values, $*$ and $* *$ are significant at $p<.05$ and $p<.01$ levels respectively.

The variance parameter $\gamma$, which lies between zero and one, indicates the ratio of the variation of firm-specific technical efficiency to the total value of output. The value of $\gamma$ reflects the distance to the efficient frontier, and thereby explains the extent of inefficiency. A higher value of $\gamma$ also shows that the majority of the error was due to variation in inefficiency. The analysis made in Table 5 shows that the range of $\gamma$ values in different sectors varied between 0.314 and 0.841 and these values were also found to be statistically significant at $1 \%$ level. It implies that the variation in the error term among the firms was due to the difference in technical 
efficiency which ranged between $31.4 \%$ (Chemicals sector) and $84.1 \%$ (Pharmaceutical and Biotechnology sector). In other words, the variance of the inefficiency effects was a significant component of the total error term variance and thus, firms' deviations from the optimal behaviour were not only due to random factors.

$\sigma^{2}$ represents the variation in efficiency among the firms. The range of estimated values of $\sigma^{2}$ in different sectors fluctuated between 0.0216 and 2.577 and all the predicted values of $\sigma^{2}$ were found to be statistically significant at $1 \%$ level. It symbolises that a significant variation in the efficiency levels amongst the firms that belong to the different sectors in the manufacturing industry was present during the period of study.

$\mu$ is the measure of inefficiency in the model. Table 5 discloses that all the values of $\mu$ for different sectors were found to be positive and significant except in the case of Electrical Equipment sub-sector. Such positive and statistically significant values of $\mu$ indicate the existing inefficiency amongst the firms operating in the different sectors in the manufacturing industry. However, the value of $\mu$ in case of the Electrical Equipment sub-sector was found to be negative and significant. It implies that the firms that belong to the Electrical Equipment industry were efficient in production. In fact, Electrical Equipment sub-sector was found to be the most efficient sub-sector out of all the selected sub-sectors. It can also be verified from the individual technical efficiency scores of the Electrical Equipment firms during the period under study.

The estimated value of $\eta$ represents the change in inefficiency among the firms operating during the period under study. The values of $\eta$ for sub-sectors Auto Parts and Equipment, Chemicals, Steel, and Textile were positive but not found to be statistically significant. It implies that the increase in the efficiency of these subsectors were not at all noticeable during the study period. The values of $\eta$ for the remaining sectors were negative and found to be statistically significant. It indicates that the inefficiency in the firms that belong to those sectors reduced significantly during the study period. However, a similar kind of justification for the negative and significant value of $\eta$ in the Electrical Equipment sub-sector is not tenable since the estimated value of $\mu$ in this sector was also negative and found to be statistically significant. Such a negative value of $\eta$ in the Electrical Equipment sector signifies that the efficiency of the firms operating in this sector declined significantly during the period of study. The estimated average technical efficiency score for all the firms in the initial year under study was found to be 0.98 whereas the same in the 
ultimate year of the study period was 0.72 . This is also consistent with the estimated average technical efficiency scores in all the Electrical Equipment firms during the period of study.

\section{Measurement of Efficiency}

Table 6 presents the descriptive statistics [Mean, Standard Deviation (S.D.), Coefficient of Variation (C.V.), Maximum, and Minimum] of efficiency estimates in the different sub-sectors of the manufacturing industry. The mean efficiency was the highest in Electrical Equipment sector (0.90) and it was followed by the subsectors Auto Parts and Equipment (0.73), Pharmaceutical and Biotechnology (0.54), Chemicals (0.44), Textile (0.35), Food products $(0.22)$ and Steel $(0.13)$ respectively.

Table 6: Descriptive Statistics of Efficiency Estimates

\begin{tabular}{lcccrcc}
\hline Sector & Mean & Rank & S.D. & \multicolumn{1}{c}{ C.V. } & Max & Min \\
\hline Auto Parts and Equipment & 0.73 & 2 & 0.14 & 18.71 & 0.99 & 0.01 \\
Chemicals & 0.44 & 4 & 0.16 & 35.24 & 0.94 & 0.08 \\
Electrical Equipment & 0.90 & 1 & 0.08 & 9.18 & 0.98 & 0.44 \\
Food products & 0.22 & 6 & 0.21 & 95.97 & 0.76 & 0.05 \\
Pharmaceutical and Biotechnology & 0.54 & 3 & 0.18 & 32.57 & 0.92 & 0.13 \\
Steel & 0.13 & 7 & 0.16 & 129.22 & 0.84 & 0.02 \\
Textile & 0.35 & 5 & 0.16 & 434 & 0.93 & 0.16 \\
\hline
\end{tabular}

The variation of efficiency was relatively low in the sub-sectors Electrical Equipment, and Auto Parts and Equipment whereas the same was found to be much higher in the sub-sectors Steel, Food products, Pharmaceutical and Biotechnology and Construction and Engineering. It is observed that in the sub-sectors where the estimated values of efficiency were more than 0.50, (such as Auto Parts and Equipment, Pharmaceutical and Biotechnology and Electrical Equipment) the corresponding predicted values of $\gamma$ in the production function were also found to be more than 0.50. On the other hand, in the Chemicals, Construction and Engineering, and Food sub-sectors both observed efficiency scores and predicted $\gamma$ values were found to be less than 0.50. It again confirms that the variation in the error term among the firms was due to the difference in technical efficiency.

\section{Descriptive Statistics of the Firm-specific Factors:}

Table 7 presents the descriptive statistics for all the variables in the different sub-sectors of the manufacturing industry which reflect the underlying distinct features of the sectors. It is seen that the average value of leverage as indicated by the Debt/Equity Ratio was the highest in the Steel sub-sector (2.54) whereas it was 
found to be the least in the Auto Parts and Equipment sub-sector (0.85). It is also seen that Electrical Equipment, and Pharmaceutical and Biotechnology sub-sectors maintained relatively low leverage whereas the financial risk associated with other sub-sectors such as Cement, Chemicals, Textile and Food products were comparatively higher. The high values of S.D. and C.V. of debt-equity ratio suggest that there was wide variation among the companies operating within different subsectors in terms of the leverage. Table 5 shows that as far as the growth of the firms is concerned, the highest average rate of growth was achieved by Steel sub-sector (56.24\%). In the remaining sub-sectors, the rate of growth varied between $15.50 \%$ and $24.24 \%$ and no wide difference between the rates of growth of the firms across these sub-sectors was observed. However, it is to be noted that huge differences in the rate of growth across the different firms that belong to the Steel sub-sector were noticed. The ranges of the size and age of the firms across different sub-sectors were found to be 4.75 to 6.40 and 3.16 to 3.54 respectively. Moreover, the variations in respect of both size and age of the firms within and across the different sub-sectors were observed to be low. The openness of the firms was observed to be the highest (0.43) in case of the Pharmaceutical and Biotechnology sub-sector and the lowest (0.15) in the Food products sub-sector. The values of C.V. in respect of openness of all sub-sectors were found to be considerably higher indicating the presence of significant variation of openness among the firms operating in the different industries during the period of study.

Table 7: Descriptive Statistics of the Determinants of the Efficiency

\begin{tabular}{|c|c|c|c|c|c|c|c|c|}
\hline$\frac{\mathscr{e}}{\frac{0}{0}}$ & 苞 & 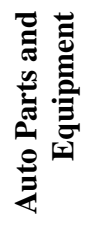 & 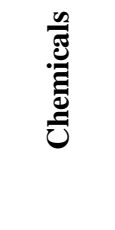 & 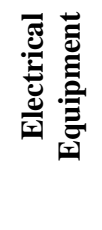 & 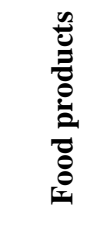 & 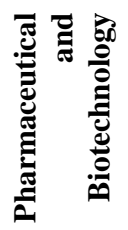 & 离 & 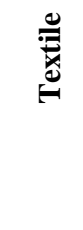 \\
\hline \multirow[t]{3}{*}{ Leverage } & Mean & 0.85 & 1.63 & 1.01 & 1.26 & 0.77 & 2.54 & 2.17 \\
\hline & SD & 0.84 & 2.86 & 0.91 & 1.27 & 0.78 & 2.68 & 1.88 \\
\hline & $\mathrm{CV}$ & 98.74 & 175.81 & 90.48 & 100.79 & 101.44 & 105.25 & 86.32 \\
\hline \multirow[t]{3}{*}{ Growth } & Mean & 15.50 & 20.24 & 21.17 & 24.24 & 21.23 & 56.24 & 15.79 \\
\hline & SD & 6.55 & 28.37 & 14.61 & 40.69 & 18.56 & 195.38 & 24.57 \\
\hline & $\mathrm{CV}$ & 42.25 & 140.16 & 69.02 & 167.91 & 87.42 & 347.40 & 15.61 \\
\hline \multirow[t]{3}{*}{ Size } & Mean & 5.12 & 4.75 & 5.61 & 4.81 & 5.16 & 5.97 & 5.17 \\
\hline & $\mathrm{SD}$ & 1.50 & 1.46 & 1.82 & 1.66 & 1.77 & 2.23 & 1.46 \\
\hline & $\mathrm{CV}$ & 29.25 & 30.70 & 32.37 & 34.54 & 34.41 & 37.39 & 28.32 \\
\hline Age & Mean & 3.37 & 3.39 & 3.39 & 3.16 & 3.27 & 3.16 & 3.33 \\
\hline
\end{tabular}




\begin{tabular}{|c|c|c|c|c|c|c|c|c|}
\hline 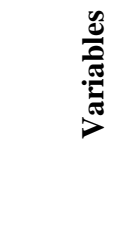 & 浐 & 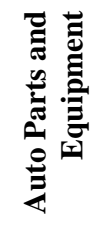 & 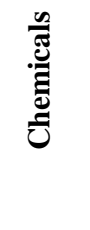 & 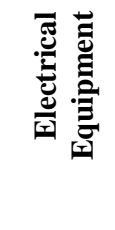 & 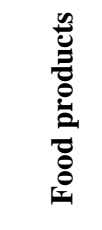 & 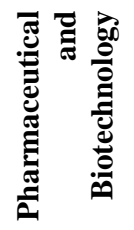 & $\frac{\bar{\Phi}}{\Phi}$ & 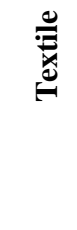 \\
\hline \multirow{5}{*}{ Openness } & SD & 0.62 & 0.44 & 0.53 & 0.52 & 0.50 & 0.55 & 0.53 \\
\hline & $\mathrm{CV}$ & 18.44 & 13.03 & 166 & 16.37 & 15.26 & 17.51 & 16.02 \\
\hline & Mean & 0.23 & 0.32 & 0.30 & 0.15 & 0.43 & 0.22 & 0.35 \\
\hline & SD & 0.25 & 0.23 & 0.31 & 0.24 & 0.32 & 0.21 & 0.34 \\
\hline & $\mathrm{CV}$ & 106.99 & 71.80 & 103.66 & 168.19 & 74.58 & 95.76 & 96.67 \\
\hline Exchange & Mean & 4.64 & 4.64 & 4.64 & 4.64 & 4.64 & 4.64 & 4.64 \\
\hline \multirow[t]{2}{*}{ Rate } & $\mathrm{SD}$ & 0.05 & 0.05 & 0.05 & 0.05 & 0.05 & 0.05 & 0.05 \\
\hline & $\mathrm{CV}$ & 1.09 & 1.09 & 1.09 & 1.09 & 1.09 & 1.09 & 1.09 \\
\hline \multirow[t]{3}{*}{ Inflation } & Mean & 4.80 & 4.80 & 4.80 & 4.80 & 4.80 & 4.80 & 4.80 \\
\hline & SD & 0.27 & 0.27 & 0.27 & 0.27 & 0.27 & 0.27 & 0.27 \\
\hline & $\mathrm{CV}$ & 60 & 60 & 60 & 60 & 60 & 60 & 60 \\
\hline
\end{tabular}

Industry wise variation can be better understood using radar plot in a snapshot form. In Figure 1 the radar plots of efficiency and different independent microeconomic variables with reference to the different sub-sectors within the manufacturing industries are presented. Inter-sub-sector variations in the plot reflect the underlying distinct features of the sectors.

In terms of the efficiency, Electric Equipment, and Auto Parts and Equipment were observed to be the two most efficient sub-sectors while Steel sub-sector registered the least efficiency during the period of study. In respect of efficiency a notable degree of variation was observed among the different sub-sectors within the manufacturing industry as indicated by the efficiency radar plot.

The average value of leverage as indicated by the Debt/Equity Ratio was the highest in the Steel sub-sector (2.54) whereas the same was found to be the lowest in the Pharmaceutical and Biotechnology sub-sector (0.77). It is also seen that Auto Parts and Equipment, and Electric Equipment sub-sectors maintained a relatively low leverage whereas the financial risk associated with other sub-sectors such as Chemicals, Textile and Food products was observed to be comparatively greater. Widely dispersed radar plot relating to Debt/Equity Ratio indicates that there was wide variation among the companies operating in different sub-sectors in terms of the leverage. 
Figure 1: Radar Plots of Variables
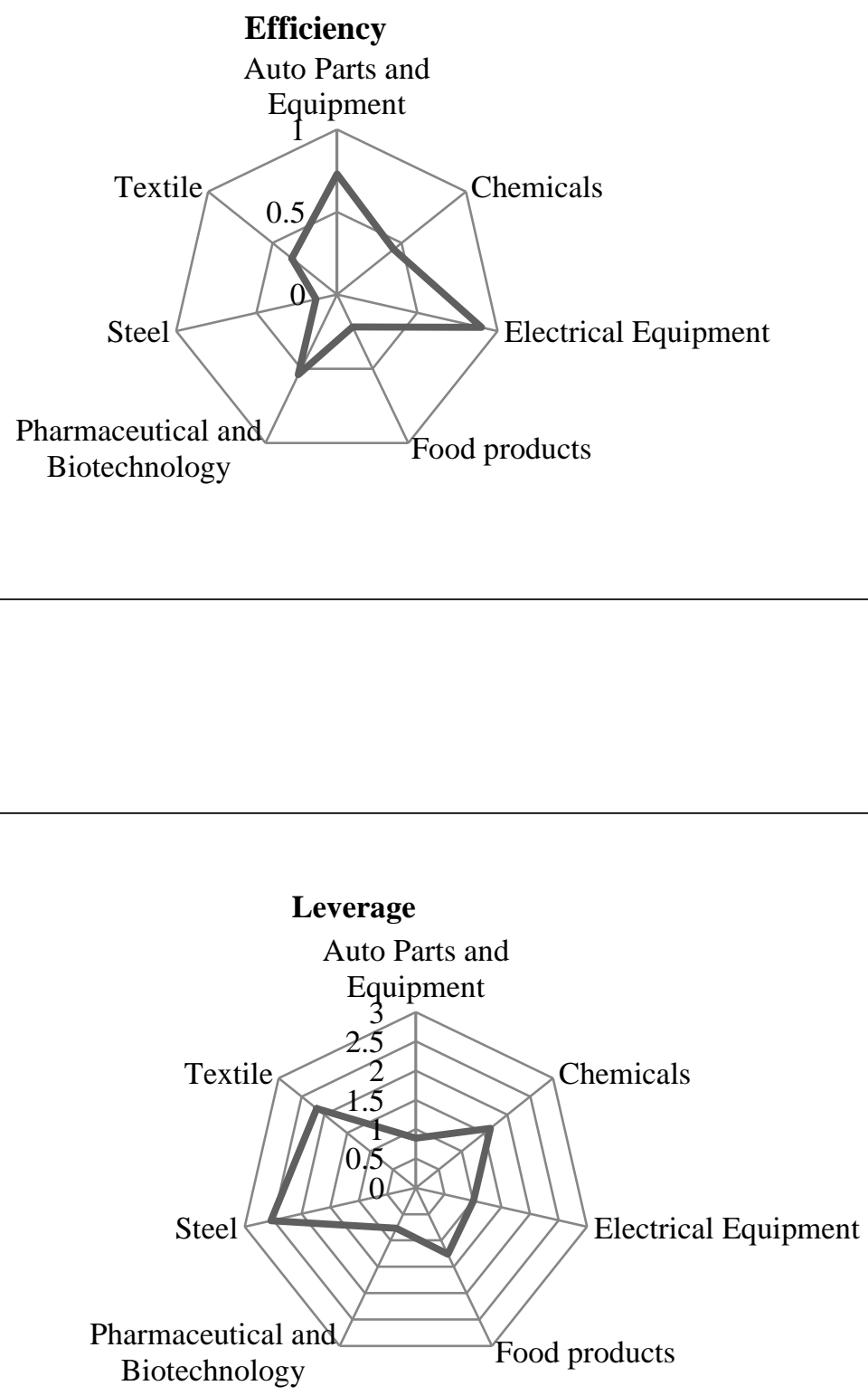
Figure 1: Radar Plots of Variables (Continued)
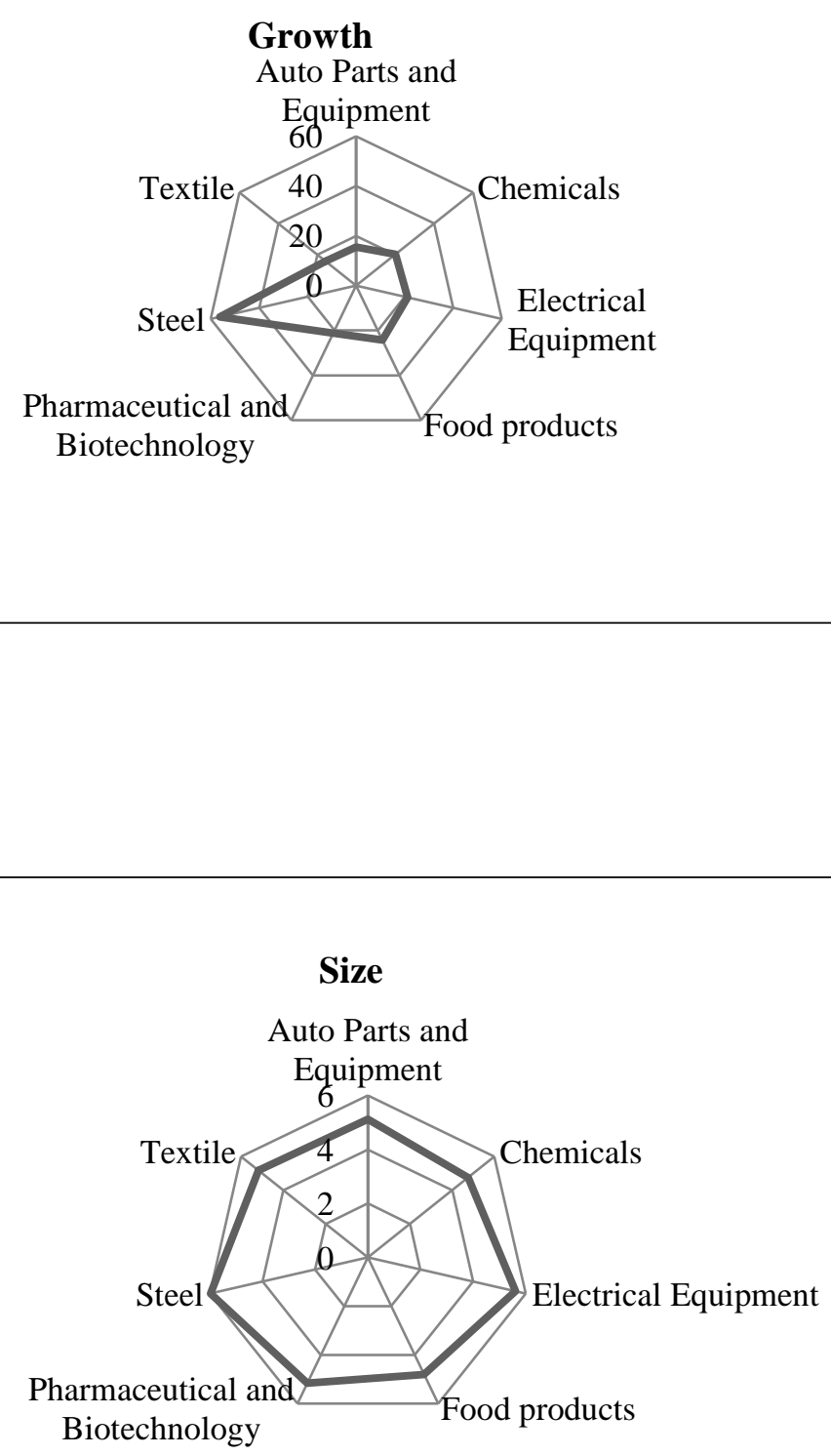
Figure 1: Radar Plots of Variables (Continued)

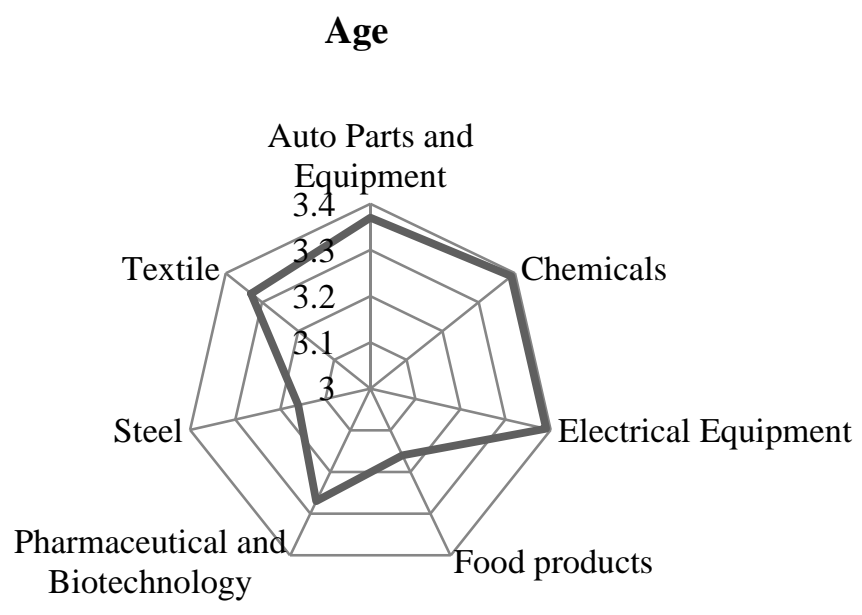

\section{Openness}

Auto Parts and

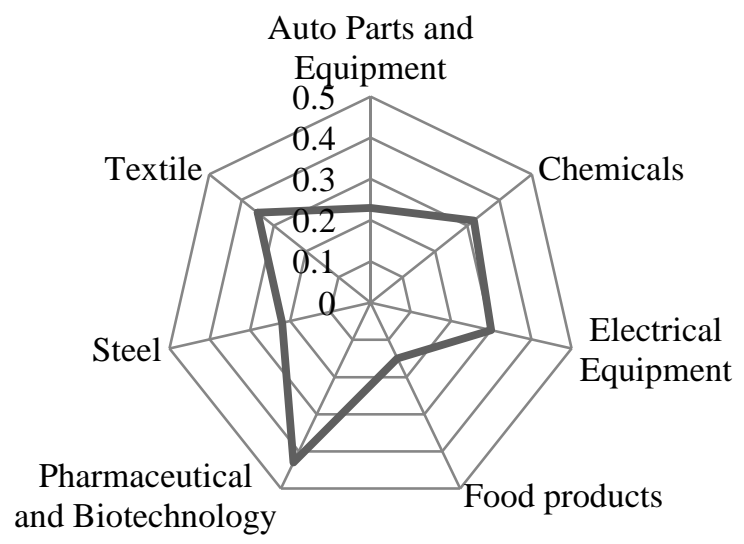




\section{Determinants of Efficiency}

The implications of firm specific and macroeconomic variables in determining the level of technical efficiency in the different manufacturing sectors are presented in Table 8. As far as the impact of financial leverage on efficiency is concerned, it is argued that firms relying more on debt are expected to be more efficient because the managers have to monitor the operating and functional activities cautiously (Majumdar, 1997). Greater financial burden in the form of fixed interest payment obligation induces greater discipline among the managers (Grossman \& Hart, 1982; Opler \& Titman, 1993) and forces them to act for the benefit of investors (Jensen, 1986). It is observed from the analysis of the determinants of efficiency that the coefficients associated with the Auto Parts and Equipment, Electrical Equipment and Food products sub-sectors were negative and found to be statistically significant which is contrary to the argument of Majumdar (1997). However, the negative impact of the leverage on the efficiency of the firms is consistent with the 'Agency Theory' which stipulates that the managers are often concerned with attaining the personal objective as compared to firm objectives (Doaei et al., 2015; Ouattara, 2012). In an alternative way Majumdar (1997) also claimed that Indian firms take their debt mostly from Public Sector Banks (PSBs) which generally fail to establish themselves efficient and in many cases, the managers of these banks are not serious enough about the productivity (greater job security in PSBs adds to that) and this can give some intuitive explanation to the burgeoning non-performing assets problem in Indian PSBs. The coefficients of leverage in the remaining sub-sectors namely Chemicals, Pharmaceutical and Biotechnology, Steel and Textile were not found to be statistically significant.

It is a widely accepted belief that engagement in the international trade, learning by exporting and exposure to the foreign markets lead to greater efficiency (Bigstein et al., 2004; Van Biesebroeck, 2005). Moreover, a relatively open firm enjoys economies of scale owing to large customer base in different geographies, greater innovation, enhanced bargaining power in the factor market, exploitation of market imperfections, profitable use of the intangibles, resource endowment in different geographies, organisational learning and risk mitigation by the way of geographical diversification (Hitt et al., 1997; Lu \& Beamish, 2004). A firm has to compete hard in order to become successful in the international market as it has to face foreign competition. The analysis made in Table 8 shows that relatively open firms that belong to the Auto Parts and Equipment, Electrical Equipment, Food products, Pharmaceutical and Biotechnology, and Textile sub-sectors were relatively more efficient than the firms operating only in the domestic market which is consistent 
Table 8: Determinants of Efficiency

\begin{tabular}{|c|c|c|c|c|c|c|c|}
\hline Variables & $\begin{array}{l}\text { Auto Parts and } \\
\text { Equipment }\end{array}$ & Chemicals & $\begin{array}{c}\text { Electrical } \\
\text { Equipment }\end{array}$ & $\begin{array}{c}\text { Food } \\
\text { products }\end{array}$ & $\begin{array}{c}\text { Pharmaceutical } \\
\text { and } \\
\text { Biotechnology }\end{array}$ & Steel & Textile \\
\hline Constant & $\begin{array}{r}0.7198487 \\
(280.64) \\
{[0.000]}\end{array}$ & $\begin{array}{r}0.3194033 \\
(45.01) \\
{[0.000]}\end{array}$ & $\begin{array}{r}2.36638 \\
(7.88) \\
{[0.000]}\end{array}$ & $\begin{array}{r}0.5834567 \\
(14.85) \\
{[0.000]}\end{array}$ & $\begin{array}{r}1.184904 \\
(18.16) \\
{[0.000]}\end{array}$ & $\begin{array}{r}0.1209774 \\
(17.83) \\
{[0.000]}\end{array}$ & $\begin{array}{r}0.3795832 \\
(1.94) \\
{[0.052]}\end{array}$ \\
\hline Leverage & $\begin{array}{r}-0.0000666 \\
(-5.26) \\
{[0.000]}\end{array}$ & $\begin{array}{r}-6.10 \mathrm{e}-06 \\
(-0.83) \\
{[0.406]}\end{array}$ & $\begin{array}{r}-0.0071448 \\
(-4.55) \\
{[0.000]}\end{array}$ & $\begin{array}{r}-0.0001645 \\
(-1.97) \\
{[0.049]}\end{array}$ & $\begin{array}{r}0.0002579 \\
(0.90) \\
{[0.370]}\end{array}$ & $\begin{array}{r}3.58 \mathrm{e}-06 \\
(0.56) \\
{[0.574]}\end{array}$ & $\begin{array}{r}0.0002472 \\
(0.60) \\
{[0.547]}\end{array}$ \\
\hline Growth & $\begin{array}{r}1.41 \mathrm{e}-06 \\
(1.61) \\
{[0.108]}\end{array}$ & $\begin{array}{r}7.75 \mathrm{e}-07 \\
(1.56) \\
{[0.118]}\end{array}$ & $\begin{array}{r}0.0000425 \\
(0.83) \\
{[0.409]}\end{array}$ & $\begin{array}{r}-9.16 \mathrm{e}-07 \\
(-0.43) \\
{[0.660]}\end{array}$ & $\begin{array}{r}8.36 \mathrm{e}-06 \\
(1.37) \\
{[0.172]}\end{array}$ & $\begin{array}{r}-1.69 \mathrm{e}-07 \\
(-1.18) \\
{[0.236]}\end{array}$ & $\begin{array}{r}0.0000153 \\
(0.77) \\
{[0.440]}\end{array}$ \\
\hline Size & $\begin{array}{r}0.003894 \\
(26.00) \\
{[0.000]}\end{array}$ & $\begin{array}{r}0.0002715 \\
(6.86) \\
{[0.000]}\end{array}$ & $\begin{array}{r}0.0036337 \\
(0.76) \\
{[0.450]}\end{array}$ & $\begin{array}{r}0.0002959 \\
(0.78) \\
{[0.434]}\end{array}$ & $\begin{array}{r}-0.0045007 \\
(-8.06) \\
{[0.000]}\end{array}$ & $\begin{array}{r}-0.0001888 \\
(-7.15) \\
{[0.000]}\end{array}$ & $\begin{array}{r}0.0101042 \\
(3.38) \\
{[0.001]}\end{array}$ \\
\hline Age & $\begin{array}{r}0.0070183 \\
(138.39) \\
{[0.000]}\end{array}$ & $\begin{array}{r}-0.0050664 \\
(-36.99) \\
{[0.000]}\end{array}$ & $\begin{array}{r}0.00324 \\
(0.16) \\
{[0.870]}\end{array}$ & $\begin{array}{r}-0.0371372 \\
(-25.10) \\
{[0.000]}\end{array}$ & $\begin{array}{r}0.0118199 \\
(6.62) \\
{[0.000]}\end{array}$ & $\begin{array}{r}-0.0017654 \\
(-17.50) \\
{[0.000]}\end{array}$ & $\begin{array}{r}-0.0224655 \\
(-1.32) \\
{[0.188]}\end{array}$ \\
\hline Openness & $\begin{array}{r}0.0002286 \\
(2.98) \\
{[0.003]}\end{array}$ & $\begin{array}{r}-0.0002095 \\
(-1.00) \\
{[0.318]}\end{array}$ & $\begin{array}{r}0.0621156 \\
(3.56) \\
{[0.000]}\end{array}$ & $\begin{array}{r}0.0077798 \\
(2.07) \\
{[0.038]}\end{array}$ & $\begin{array}{r}0.0060215 \\
(2.70) \\
{[0.007]}\end{array}$ & $\begin{array}{r}-0.0009291 \\
(-4.15) \\
{[0.000]}\end{array}$ & $\begin{array}{r}0.0161105 \\
(1.73) \\
{[0.084]}\end{array}$ \\
\hline
\end{tabular}




\begin{tabular}{|c|c|c|c|c|c|c|c|}
\hline Variables & $\begin{array}{c}\text { Auto Parts and } \\
\text { Equipment }\end{array}$ & Chemicals & $\begin{array}{c}\text { Electrical } \\
\text { Equipment }\end{array}$ & $\begin{array}{c}\text { Food } \\
\text { products }\end{array}$ & $\begin{array}{c}\text { Pharmaceutical } \\
\text { and } \\
\text { Biotechnology } \\
\end{array}$ & Steel & Textile \\
\hline $\begin{array}{l}\text { Exchange } \\
\text { Rate }\end{array}$ & $\begin{array}{r}-0.0000918 \\
(-0.14) \\
{[0.887]}\end{array}$ & $\begin{array}{r}-0.0043301 \\
(-2.44) \\
{[0.015]}\end{array}$ & $\begin{array}{r}0.0492045 \\
(0.65) \\
{[0.517]}\end{array}$ & $\begin{array}{r}0.00648 \\
(0.66) \\
{[0.507]}\end{array}$ & $\begin{array}{r}0.0175812 \\
(1.08) \\
{[0.281]}\end{array}$ & $\begin{array}{r}-0.0008687 \\
(-0.51) \\
{[0.609]}\end{array}$ & $\begin{array}{r}-0.0015333 \\
(-0.03) \\
{[0.975]}\end{array}$ \\
\hline $\begin{array}{l}\text { Wald Chi } \\
\text { square }\end{array}$ & $\begin{array}{r}26318.74 \\
{[0.000]}\end{array}$ & $\begin{array}{r}25087.12 \\
{[0.000]}\end{array}$ & $\begin{array}{r}1010.29 \\
{[0.000]}\end{array}$ & $\begin{array}{r}6104.88 \\
{[0.000]}\end{array}$ & $\begin{array}{r}5663.13 \\
{[0.000]}\end{array}$ & $\begin{array}{r}562.10 \\
{[0.000]}\end{array}$ & $\begin{array}{r}18.11 \\
{[0.000]}\end{array}$ \\
\hline $\begin{array}{l}\text { Log- } \\
\text { likelihood }\end{array}$ & 4156.9403 & 5355.7576 & 641.11793 & 1174.3794 & 2406.3661 & 3118.6574 & 1820.4024 \\
\hline
\end{tabular}

Note: Values in parenthesis and square brackets indicate $Z$ values and $p$ values respectively 
with the arguments of Doaei et al. (2015), Baliyan and Baliyan (2015), Gambir and Sharma (2015) and Chang and Wang (2007). However, the coefficient associated with the openness was negative and found to be statistically significant in the Steel sub-sector9. The coefficient of exchange rate in this sector was also found to be negative (although insignificant) which to some extent intuitively implies that the importing firms in this sector were found to be relatively inefficient as compared to their competitors. It is generally found that in a situation of devaluation of domestic currency, the import cost and thereby the total cost enhance significantly and that ultimately exerts notable negative effect on the efficiency of the firms.

It is generally argued that large size firms can have better financial performance because of their ability of diversification, economies of scale, bargaining power, easy access to cheaper financial resources and formalisation of procedure (Firth et al., 2015; Halkos \& Tzeremes, 2007; Kalaitzandonakes et al, 1992; Lundvall \& Battese, 2000; Majumdar, 1997; Pitt \& Lee, 1981; Söderbom \& Teal, 2004). The analysis made in Table 8 reveals that the effect of firm size on the technical efficiency was observed to be positive and statistically significant in case of the firms that belong to the Auto Parts and Equipment, Chemicals, and Textile subsectors. Bhandari and Maiti (2007) in their study also observed positive effect of the size of the Textile firms on the technical efficiency during 2000-2001. Thus, it can be concluded that larger firms that belong to these sub-sectors could exploit the economies of scale along with other associated advantages, which is reflected in higher efficiency of larger firms' vis-à-vis smaller firms during the period of study. However, the coefficients associated with the size of the firms operating in Pharmaceutical and Biotechnology and Steel sub-sectors, were negative which were found to be statistically significant. Theoretically, such a situation may arise on account of market power concentration which generates market power inefficiencies (X-inefficiency) and therefore, leads to inefficient performance (Leibenstein, 1976). The idea of X-inefficiency suggests that, economies of scale can be enjoyed by large firms in an industry provided that there are firms of varying sizes operating in an industry. However, if in an industry most of the firms are of same size then benefit of large size decays gradually which leads to inefficiency. In addition to that, it is also argued that large size firms in the Indian manufacturing sector are very much satisfied and contained with the prevailing situation and thus there is no initiative in improving the efficiency or reducing the cost (Majumdar, 1997). Moreover, size of the firm often determines the potentials of growth of the firm. The

\footnotetext{
${ }^{9}$ The average import expenditure of firms belonging to Steel Sector stepped up from Rs. 977.4 million in 19992000 to Rs. 1,307.16 million during 2013-14.
} 
coefficient associated with the growth of the firms in the Auto Parts and Equipment sub-sector was positive and was also found to be statistically significant. Interestingly, it was also noticed that similar kind of signs persists in case of the coefficients of the firm size in this sub-sector. The relatively large firms in the Auto Parts and Equipment sub-sector were adopting growth strategy and thus these two factors complemented each other in augmenting the level of efficiency. The coefficients of growth in all other sectors were not found to be statistically significant.

In accordance with the 'Learning Curve Effect' proposition, the experienced firms are better able to put the available resources to productive use (Harvie, 2004; Pelham, 2000; Weston \& Mansinghka, 1971). In addition to this the formalisation of the procedure, with increasing age, also contributes positively in the level of efficiency of the firms. Beaver (1966) also suggests that the probability of failure of the old firms is generally lower as compared to that of the newer ones. The analysis made in Table 8 shows that the coefficients of firm age were positive and found to be statistically significant in the case of firms that belong to the Auto Parts and Equipment and Pharmaceutical and Biotechnology sub-sectors which are consistent with this theoretical conviction. However, age of the firm produced negative effect in case of the Chemicals, Food products and Steel sub-sectors which signifies that new firms in these sub-sectors outperformed the older ones in ensuring efficiency in production. The underlying economic logic may be that newer firms enter into the market with the new technology, innovative ideas, and flexibility in adapting the dynamic business environment, and thus they are more efficient (Le \& Harvie, 2010). In addition, it is also believed that older firms are likely to suffer from inertia and thus fail to make adjustment with the changing business environment. As a result, they gradually become inefficient (Marshall, 1920).

It is evident from the result of the study that the exchange rate was an insignificant determinant of the efficiency of the firms in all other sub-sectors except Chemicals. The coefficient of the exchange rate in case of the Chemicals sub-sector was negative and found to be statistically significant which is consistent with the sign associated with the coefficient of openness of firms in that sub-sector. It implies that majority of the firms that belong to this sub-sector were dependent on international trade for importing raw materials and thereby vulnerable to the devaluation of the exchange rate. The analysis of the data of the Chemicals subsector as a whole reveals that the average import expenditure for this sector has increased from Rs. 269.01 million in 1999-2000 to Rs. 2,530.3 million in 20132014. RBI statistics suggest that the Real Effective Exchange Rate stepped up from 
Rs. 99.43 in 1999-2000 to Rs. 104.50 in 2013-2014. Similar kind of observation was also revealed in the study made by Doaei et al. (2015) where the study suggested that the exchange rate exerted significant negative impact on the technical efficiency of the manufacturing firms in Malaysia. Moreover, Hitt et al. (1997) suggested that the relationship between the international diversification as indicated by openness and the financial performance is curvilinear in nature i.e. firm performance improves initially, with international diversification but after some period of time it will decline with further international diversification.

The study reveals that inflation in the economy had a significant negative impact on the level of the efficiency of the firms operating in the Auto Parts and Equipment, electrical equipment, Pharmaceutical and Biotechnology and Textile sub-sectors. In an inflationary situation, the cost of the production goes up which makes it difficult to ensure efficiency of the firms. As suggested by De Fina (1991), the rate of growth of cash flow is lower than that of inflation and the revenue and cost of the firm will take time to adjust. In simple words, the cost of input increases on account of inflation but it takes more time to adjust output prices. Thus, it can be said that the firms that belong to these sectors could not cope up with the cost push inflationary situation, which may have restricted the firms to ensure optimum level of efficiency. However, the firms that belong to the Chemicals and Steel sub-sectors were found to be resilient and more disciplined in absorbing inflationary shock and thereby performed efficiently even in inflationary situation.

\section{Conclusion}

In today's challenging and intensely competitive environment, firms operating in different sectors must operate efficiently to survive in the long run. The present study attempted to shed some light on the technical efficiency of the firms that belong to the different sectors in the Indian manufacturing industry by using Stochastic Frontier Analysis. The study revealed that the firms that belong to the Auto Parts and Equipment, Chemicals, Electrical equipment, Food products, Pharmaceutical and Biotechnology, Steel and Textile sub-sectors could utilise the available resources effectively to generate the value of output during the study period. The study also indicated that there existed inefficiency among the firms operating under different sub-sectors and, at the same time, variation of efficiency among the firms that belong to different sub-sectors was present during the study period.

The present study also made an effort to inquire into the determinants of the efficiency of the firms in terms of the different firm-specific and macroeconomic 
factors to identify the distinct underlying characteristics of the different sub-sectors within the broad manufacturing industry. The study showed that firm-specific factors did not affect equally the efficiency of the firms that belong to the different sub-sectors. The efficiency of Auto Parts and Equipment sub-sector was primarily driven by leverage, age, growth, size, openness and inflation. Similarly, size, age, rate of exchange and inflation had significant effect on the efficiency of firms in the Chemicals sub-sector. The efficiency in the Electrical equipment sub-sector was mainly influenced by leverage, openness and inflation. On the other hand, the efficiency of the Food product sector was affected by leverage, age, openness and inflation. Moreover, the firm size and openness established themselves as the important predictors for firm level technical efficiency in the Pharmaceutical and Biotechnology, and Steel and Textile sub-sectors respectively. In addition to that, firm age and inflation were also observed to be the major determinants of efficiency for the firms that belong to the Steel and, Pharmaceutical and Biotechnology subsectors.

\section{Declaration of Conflict of Interest}

The authors declared no potential conflict of interest with respect to the research, authorship, and publication of this article.

\section{References}

Ahmed, M. S., \& Ahmed, M. D. (2013). Efficiency variation of manufacturing firms: A case study of seafood processing firms in Bangladesh. Review of Economics and Finance, 3(2), 45-56.

Aigner, D., Lovell, C. A. K., \& Schmidt, P. (1977). Formulation and estimation of stochastic frontier production function models. Journal of Econometrics, 6(1), 21-37. https://doi.org/10.1016/0304-4076(77)90052-5

Alvarez, R., \& Crespi, G. (2003). Determinants of technical efficiency in small firms. Small Business Economics, 20(3), 233-244. https://doi.org/10.1023/ A:1022804419183

Baek, H. Y., \& Neymotin, F. (2016). International involvement and production efficiency among startup firms. Global Economic Review,45(1), 42-62. https://doi.org/10.1080/1226508X.2015.1084240

Baliyan, S. K., \& Baliyan, K. (2015). Determinants of firm-level performance: A study of Indian manufacturing and service sectors. Indian Journal of Economics and Development, 11(3), 701-713. https://doi.org/10.5958/2322-0430.2015. $\underline{00078.5}$ 
Banker, R.D., Gadh, V.M., \& Gorr, W.L. (1993). A Monte Carlo comparison of two production frontier estimation methods: Corrected ordinary least squares and data envelopment analysis. European Journal of Operational Research 67(3), 332-343. https://doi.org/10.1016/0377-2217(93)90289-Y

Basu, D., \& Das, D. (2015). Profitability in India's Organized Manufacturing Sector: The Role of Technology, Distribution, and Demand (Working Paper, No. 2015-04). University of Massachusetts, Department of Economics, Amherst, MA.). https://www.econstor.eu/bitstream/10419/145413/1/821606948.pdf

Beaver, W. H. (1966). Financial ratios as predictors of failure. Journal of Accounting Research, 4, 71-111. https://www.jstor.org/stable/2490171

Bhandari, A. K., \& Maiti, P. (2007). Efficiency of Indian manufacturing firms: Textile industry as a case study. International Journal of Business and Economics, 6(1), 71-88.

Bhavani, T. A. (1991). Technical efficiency in Indian modern small scale sector: An application of frontier production function. Indian Economic Review, 26(2), 149-166.

Biener, C., Eling, M., \& Wirfs, J. H. (2016). The determinants of efficiency and productivity in the Swiss insurance industry. European Journal of Operational Research, 248(2), 703-714. https://doi.org/10.1016/j.ejor.2015.07.055

Bigsten, A., Collier, P., Dercon, S., Fafchamps, M., Gauthier, B., Willem Gunning, J., Oduro, A., Oostendorp, R., Pattillo, C., Söderbom, M., Teal, F., \& Zeufack, A. (2004). Do African manufacturing firms learn from exporting? Journal of Development Studies, 40(3), 115-141. https://doi.org/10.1080/0022038042 $\underline{000213229}$

Blomström, M. (1986). Foreign investment and productive efficiency: The case of Mexico. The Journal of Industrial Economics, 35(1), 97-110. https://www.jstor.org/stable/2098609

Burki, A. A., \& Terrell, D. (1998). Measuring production efficiency of small firms in Pakistan. World Development, 26(1), 155-169. https://doi.org/10.1016/ $\underline{\text { S0305-750X(97)00122-8 }}$

Castiglione, C., \& Infante, D. (2014). ICTs and time-span in technical efficiency gains. A stochastic frontier approach over a panel of Italian manufacturing firms. Economic Modelling, 41, 55-65. https://doi.org/10.1016/j.econmod.2014.04. 021

Chang, S. C., \& Wang, C. F. (2007). The effect of product diversification strategies on the relationship between international diversification and firm performance. Journal of World Business, 42(1), 61-79. https://doi.org/10.1016/ j.jwb.2006.11.002 
Chapelle, K., \& Plane, P. (2005). Technical efficiency measurement within the manufacturing sector in Côte d'Ivoire: A stochastic frontier approach. Journal of Development Studies, 41(7), 1303-1324. https://doi.org/10.1080/002203805001 $\underline{70964}$

Charnes, A., Cooper, W. W., \& Rhodes, E. (1978). Measuring the efficiency of decision making units. European Journal of Operational Research, 2(6), 429444. https://doi.org/10.1016/0377-2217(78)90138-8

Chuang, Y. C., \& Lin, C. M. (1999). Foreign direct investment, R\&D and spillover efficiency: Evidence from Taiwan's manufacturing firms. The Journal of Development Studies, 35(4), 117-137. https://doi.org/10.1080/002203899084 22583

Coelli, T. J. (1996). A guide to FRONTIER version 4.1: A computer program for stochastic frontier production and cost function estimation (CEPA Working paper number 96/07). http://iranarze.ir/wp-content/uploads/2017/07/7209English-IranArze.pdf

Cull, R., Xu, L. C., Yang, X., Zhou, L. A., \& Zhu, T. (2017). Market facilitation by local government and firm efficiency: Evidence from China. Journal of Corporate Finance, 42, 460-480. https://doi.org/10.1016/j.jcorpfin.2015.06.002

Cullinane, K., Wang, T. F., Song, D. W., \& Ji, P. (2006). The technical efficiency of container ports: Comparing data envelopment analysis and stochastic frontier analysis. Transportation Research Part A: Policy and Practice, 40(4), 354-374. https://doi.org/10.1016/j.tra.2005.07.003

De Fina, R. H. (1991, Nov). Does inflation depress the stock market. Business Review, 3-12. Federal Reserve Bank of Philadelphia.

Diaz-Balteiro, L., Herruzo, A. C., Martinez, M., \& Gonzalez-Pachon, J. (2006). An analysis of productive efficiency and innovation activity using DEA: An application to Spain's wood-based industry. Forest Policy and Economics, 8(7), 762-773. https://doi.org/10.1016/j.forpol.2005.06.004

Din, M. U., Ghani, E., \& Mahmood, T. (2007). Technical efficiency of Pakistan's manufacturing sector: A stochastic frontier and data envelopment analysis. The Pakistan Development Review, 46(1), 1-18.

Doaei, M., Anuar, M. A., \& Ismail, Z. (2015). Corporate diversification and efficiency of manufacturing firms listed in Bursa Malaysia. Iranian Journal of Management Studies, 8(4), 523-543. https://doi.org/10.22059/IJMS.2015.55000

Driffield, N. L., \& Kambhampati, U. S. (2003). Trade liberalization and the efficiency of firms in Indian manufacturing. Review of Development Economics, 7(3), 419-430. https://doi.org/10.1111/1467-9361.00200

Dwivedi, A. K., \& Ghosh, P. (2014). Efficiency measurement of Indian sugar manufacturing firms: A DEA approach (CREED Working Paper No. 
CREED/2014/01). http://library.ediindia.ac.in:8181/xmlui/bitstream/ handle/ 123456789/1834/Efficiency\%20Measurement\%20of\%20Indian\%20Sugar\%20 Manufacturing\%20Firms\%20A\%20DEA\%20Approach.pdf?sequence=1\&isAll owed=y.

Felipe, J., Mehta, A., \& Rhee, C. (2018). Manufacturing matters...but it's the jobs that count. Cambridge Journal of Economics, 43(1), 139-168. https://doi.org/ 10.1093/cje/bex086

Ferrantino, M. J. (1992). Technology expenditures, factor intensity, and efficiency in Indian manufacturing. The Review of Economics and Statistics, 74(4), 689700. https://www.jstor.org/stable/2109383

Firth, M., Leung, T. Y., Rui, O. M., \& Na, C. (2015). Relative pay and its effects on firm efficiency in a transitional economy. Journal of Economic Behavior \& Organization, 110, 59-77. https://doi.org/10.1016/j.jebo.2014.12.001.

Forlani, E. (2012). Competition in services and efficiency of manufacturing firms: Does 'Liberalization' Matter? (LICOS Discussion Paper No. 311). http://dx.doi. org/10.2139/ssrn.2084612

Gambhir, D., \& Sharma, S. (2015). Productivity in Indian manufacturing: Evidence from the textile industry. Journal of Economic and Administrative Sciences, 31(2), 71-85. https://doi.org/10.1108/JEAS-09-2014-0021

Gill, A. S., \& Biger, N. (2013). The impact of corporate governance on working capital management efficiency of American manufacturing firms. Managerial Finance, 39(2), 116-132. https://doi.org/10.1108/03074351311293981

Giokas, D., Eriotis, N., \& Dokas, I. (2015). Efficiency and productivity of the food and beverage listed firms in the pre-recession and recessionary periods in Greece. Applied Economics, 47(19), 1927-1941. https://doi.org/10.1080/0003 $\underline{6846.2014 .1002886}$

Golder, B., \& Kumari, A. (2003). Import liberalisation and productivity growth in Indian manufacturing in the 1990s. Developing Economies, 41(4), 436-460. https://doi.org/10.1111/j.1746-1049.2003.tb01010.x

Government of India (2013). Economic survey 2012-13. https://www.indiabudget. gov.in/budget2013-2014/survey.asp

Grossman, S. J., \& Hart, O. D. (1982). Corporate financial structure and managerial incentives (NBER Working Paper No. R0398). https://ssrn.com/ abstract $=578641$

Halkos, G. E., \& Tzeremes, N. G. (2007). Productivity efficiency and firm size: An empirical analysis of foreign owned companies. International Business Review, 16(6), 713-731. https://doi.org/10.1016/j.ibusrev.2007.06.002

Hall, B. H., Lotti, F., \& Mairesse, J. (2009). Innovation and productivity in SMEs: Empirical evidence for Italy. Small Business Economics, 33(1), 13-33. https://doi.org/10.1007/s11187-009-9184-8 
Hanousek, J., Kočenda, E., \& Shamshur, A. (2015). Corporate efficiency in Europe. Journal of Corporate Finance, 32, 24-40. https://doi.org/10.1016/ j.jcorpfin.2015.03.003

Haraguchi, N., Cheng, C. F. C., \& Smeets, E. (2017). The importance of manufacturing in economic development: Has this changed? World Development, 93, 293-315. https://doi.org/10.1016/j.worlddev.2016.12.013

Harvie, C. (2004). East Asian SME capacity building, competitiveness and market opportunities in a global economy (Department of Economics, University of Wollongong Working Paper 04-16. http://citeseerx.ist.psu.edu/viewdoc/down load?doi=10.1.1.666.272\&rep=rep1\&type $=$ pdf

Hasan, R. (2002). The impact of imported and domestic technologies on the productivity of firms: Panel data evidence from Indian manufacturing firms. Journal of Development Economics, 69(1), 23-49. https://doi.org/10.1016/ S0304-3878(02)00051-2

Hill, H., \& Kalirajan, K. P. (1993). Small enterprise and firm-level technical efficiency in the Indonesian garment industry. Applied Economics, 25(9), 1137 1144. https://doi.org/10.1080/00036849300000174

Hitt, M. A., Hoskisson, R. E., \& Kim, H. (1997). International diversification: Effects on innovation and firm performance in product-diversified firms. Academy of Management Journal, 40(4), 767-798. https://doi.org/10.5465/ $\underline{256948}$

Hjalmarsson, L., Kumbhakar, S. C., \& Heshmati, A. (1996). DEA, DFA and SFA: A comparison. Journal of Productivity Analysis, 7(2-3), 303-327. https://doi. org/10.1007/BF00157046

Hossain, M. K., Kamil, A. A., Baten, M. A., \& Mustafa, A. (2012). Stochastic frontier approach and data envelopment analysis to total factor productivity and efficiency measurement of Bangladeshi rice. Plos one, 7(10), 1-9. https://doi. org/10.1371/journal.pone.0046081

Ismail, R., \& Sulaiman, N. (2007). Technical efficiency in Malay manufacturing firms. International Journal of Business and Society, 8(2), 47-62.

Jain, N. K., Kundu, S. K., \& Newburry, W. (2015). Efficiency seeking emerging market firms: Resources and location choices. Thunderbird International Business Review, 57(1), 33-50. https://doi.org/10.1002/tie.21670

Jensen, M. C. (1986). Agency costs of free cash flow, corporate finance, and takeovers. The American Economic Review, 76(2), 323-329.

Kalaitzandonakes, N. G., Wu, S., \& Ma, J. C. (1992). The relationship between technical efficiency and firm size revisited. Canadian Journal of Agricultural Economics/Revue Canadienne d'agroeconomie, 40(3), 427-442. https://doi.org/ 10.1111/j.1744-7976.1992.tb03705.x 
Kaldor, N. (1967). Strategic factors in economic development. Cornell University.

Kambhampati, U. S., \& Parikh, A. (2005). Has Liberalization affected profit margins in Indian Industry? Bulletin of Economic Research, 57(3), 273-304. https://doi.org/10.1111/j.0307-3378.2005.00224.x

Kathuria, V., Raj, S. R., \& Sen, K. (2012). The effects of economic reforms on manufacturing dualism: Evidence from India. Journal of Comparative Economics, 41(4), 1240-1262. https://doi.org/10.1016/j.jce.2012.10.003

Kochhar, K., Kumar, U., Rajan, R., Subramanian, A., \& Tokatlidis, I. (2006). India's pattern of development: What happened, what follows? Journal of Monetary Economics, 53(5), 981-1019. https://doi.org/10.1016/j.jmoneco. $\underline{2006.05 .007}$

Kumar, S. (2006). A decomposition of total productivity growth. International Journal of Productivity and Performance Management, 55(3-4), 311-331. https://doi.org/10.1108/17410400610653255

Kumbhakar, S. C., Ghosh, S., \& McGuckin, J. T. (1991). A generalized production frontier approach for estimating determinants of inefficiency in US dairy farms. Journal of Business \& Economic Statistics, 9(3), 279-286. https://www. jstor.org/stable/1391292

Kundi, M., \& Sharma, S. (2016). Efficiency of glass firms in India: An application of data envelopment analysis. Journal of Advances in Management Research, 13(1), 59-74. https://doi.org/10.1108/JAMR-03-2015-0019

Le, V., \& Harvie, C. (2010). Firm performance in Vietnam: Evidence from manufacturing small and medium enterprises. (University of Wollongong, Faculty of Business - Economics Working Paper No. 4-10). https://ro.uow.edu.au/cgi/viewcontent.cgi?article $=1223 \&$ context=commwkpape rs

Leibenstein, H. (1976). Beyond economic man. Harvard University Press.

Lu, J. W., \& Beamish, P. W. (2004). International diversification and firm performance: The S-curve hypothesis. Academy of Management Journal, 47(4), 598-609. https://doi.org/10.5465/20159604

Lundvall, K., \& Battese, G. E. (2000). Firm size, age and efficiency: Evidence from Kenyan manufacturing firms. The Journal of Development Studies, 36(3), 146163. https://doi.org/10.1080/00220380008422632

Madheswaran, S., Liao, H., \& Rath, B. N. (2007). Productivity growth of Indian manufacturing sector: Panel estimation of stochastic production frontier and technical inefficiency. The Journal of Developing Areas, 40(2), 35-50. https://doi.org/10.1353/jda.2007.0018

Maji, S.K. (2019). Effect of macroeconomic fundamentals on the financial performance of select companies in Indian manufacturing sector during the 
post-liberalization era: An empirical quest (Doctoral thesis, The University of Burdwan, West Bengal. India.).

Majumdar, S. K. (1997). The impact of size and age on firm-level performance: Some evidence from India. Review of Industrial Organization, 12(2), 231241 .https://doi.org/10.1023/A:1007766324749

Majumdar, S. K., \& Bhattacharjee, A. (2010). The profitability dynamics of Indian firms. https://doi.org/10.5465/ambpp.2010.54501095

Marshall, A. (1920). Industry and trade. McMaster University Archive for the History of Economic Thought. https://socialsciences.mcmaster.ca/ econ/ugcm/ 3113/marshall/Industry\&Trade.pdf

McConaughy, D. L., Walker, M. C., Henderson, G. V., \& Mishra, C. S. (1998). Founding family controlled firms: Efficiency and value. Review of Financial Economics, 7(1), 1-19. https://doi.org/10.1016/S1058-3300(99)80142-6

Mitra, A. (1999). Total factor productivity growth and technical efficiency in Indian industries. Economic and Political Weekly, 34(31), M98-M105.

Mitra, A., Sharma, C., \& Veganzones, M. A. (2011). Total factor productivity and technical efficiency of Indian manufacturing: The role of infrastructure and information \& communication technology. https://www.researchgate.net/profile/ Marie Ange Veganzones/publication/228433873 Total Factor Productivity a nd Technical Efficiency of Indian Manufacturing The Role of Infrastructu re_and_Information_Communication_Technology/links/02bfe50d1fc204595f00 0000.pdf

Mitra, A., Sharma, C., \& Véganzonès-Varoudakis, M. A. (2012). Estimating impact of infrastructure on productivity and efficiency of Indian manufacturing. Applied Economics Letters, 19(8), 779-783. https://doi.org/10.1080/13504851. $\underline{2011.603687}$

Mitra, A., Varoudakis, A., \& Veganzones-Varoudakis, M. A. (2002). Productivity and technical efficiency in Indian states' manufacturing: the role of infrastructure. Economic Development and Cultural Change, 50(2), 395-426. http://dx.doi.org/10.1086/321916

Mukherjee, K., \& Ray, S. C. (2005). Technical efficiency and its dynamics in Indian manufacturing: An inter-state analysis. Indian Economic Review, 101-125.

Nazarko, J., \& Chodakowska, E. (2017). Labour efficiency in construction industry in Europe based on frontier methods: Data envelopment analysis and stochastic frontier analysis. Journal of Civil Engineering and Management, 23(6), 787795. https://doi.org/10.3846/13923730.2017.1321577

Neogi, C., \& Ghosh, B. (1994). Intertemporal efficiency variations in Indian manufacturing industries. Journal of Productivity Analysis, 5(3), 301-324. https://doi.org/10.1007/BF01073913 
Opler, T., \& Titman, S. (1993). The determinants of leveraged buyout activity: Free cash flow vs. financial distress costs. The Journal of Finance, 48(5), 1985-1999. https://doi.org/10.1111/j.1540-6261.1993.tb05138.x

O'Toole, C. M., \& Tarp, F. (2014). Corruption and the efficiency of capital investment in developing countries. Journal of International Development, 26(5), 567-597. https://doi.org/10.1002/jid.2997

Ouattara, W. (2010). Economic efficiency analysis in Coted'Ivoire. Journal of Development and Agricultural Economics, 2(9), 316-325. https://doi.org/ $\underline{10.5923 / j . e c o n o m i c s .20120201 .05}$

Pattnayak, S. S., \& Thangavelu, S. M. (2005). Economic reform and productivity growth in Indian manufacturing industries: An interaction of technical change and scale economies. Economic Modelling, 22(4), 601-615. https://doi.org/ $\underline{10.1016 / j . e c o n m o d .2004 .09 .005}$

Pelham, A. M. (2000). Market orientation and other potential influences on performance in small and medium-sized manufacturing firms. Journal of Small Business Management, 38(1), 48-67.

Piesse, J., \& Thirtle, C. (2000). A stochastic frontier approach to firm level efficiency, technological change, and productivity during the early transition in Hungary. Journal of Comparative Economics, 28(3), 473-501. https://doi.org/ $\underline{10.1006 / j c e c .2000 .1672}$

Pitt, M. M., \& Lee, L.-F. (1981). The measurement and sources of technical inefficiency in the Indonesian weaving industry. Journal of Development Economics, 9(1), 43-64. https://doi.org/10.1016/0304-3878(81)90004-3

Rajan, R. G. (2006). India: The past and its future. Asian Development Review,23(2), 36-52.

Sharma, C., \& Sehgal, S. (2010). Impact of infrastructure on output, productivity and efficiency: Evidence from the Indian manufacturing industry. Indian Growth and Development Review, 3(2), 100-121. https://doi.org/10.1108/ 17538251011084446

Sharma, S. K., \& Sehgal, S. (2015). Productivity, innovations and profitability of manufacturing industries in India: A regional study of Haryana State. International Journal of Business Excellence, 8(6), 700-723. https://doi.org/ $\underline{\text { 10.1504/IJBEX.2015.072306 }}$

Söderbom, M., \& Teal, F. (2004). Size and efficiency in African manufacturing firms: Evidence from firm-level panel data. Journal of Development Economics, 73(1), 369-394. https://doi.org/10.1016/j.jdeveco.2003.02.005

Sufian, F. (2009). Determinants of bank efficiency during unstable macroeconomic environment: Empirical evidence from Malaysia. Research in International Business and Finance, 23(1), 54-77. https://doi.org/10.1016/j.ribaf.2008.07.002 
Thatcher, M. E., \& Oliver, J. R. (2001). The impact of technology investments on a firm's production efficiency, product quality, and productivity. Journal of Management Information Systems, 18(2), 17-45. https://doi.org/10.1080/ $\underline{07421222.2001 .11045685}$

Theodoridis, A. M., \& Psychoudakis, A. (2008). Efficiency measurement in Greek dairy farms: Stochastic frontier vs. data envelopment analysis. International Journal of Economic Sciences and Applied Research, 1(2), 53-67.

Van Biesebroeck, J. (2005). Exporting raises productivity in sub-Saharan African manufacturing firms. Journal of International Economics, 67(2), 373-391. https://doi.org/10.1016/j.jinteco.2004.12.002

Vining, A. R., \& Boardman, A. E. (1992). Ownership versus competition: Efficiency in public enterprise. Public Choice, 73(2), 205-239. https://doi.org/ 10.1007/BF00145092

Weill, P. (1992). The relationship between investment in information technology and firm performance: A study of the valve manufacturing sector. Information Systems Research, 3(4), 307-333.https://doi.org/10.1287/isre.3.4.307

Weston, J. F., \& Mansinghka, S. K. (1971). Tests of the efficiency performance of conglomerate firms. The Journal of Finance, 26(4), 919-936. https://doi.org/ 10.1111/j.1540-6261.1971.tb00928.x

Yang, C.-H., \& Chen, K.-H. (2009). Are small firms less efficient? Small Business Economics, 32(4), 375-395. https://doi.org/10.1007/s11187-007-9082-X

Yang, J.-C. (2006). The efficiency of SMEs in the global market: Measuring the Korean performance. Journal of Policy Modelling, 28(8), 861-876. https://doi. org/10.1016/j.jpolmod.2006.07.004

Yu, Y. S., Barros, A., Yeh, M. L., Lu, M. J., \& Tsai, C. H. (2012). A study of estimating the technical efficiency of optoelectronic firms: An application of data envelopment analysis and tobit analysis. International Journal of Academic Research in Business and Social Sciences, 2(7), 192-202.

Zheng, J., Liu, X., \& Bigsten, A. (1998). Ownership structure and determinants of technical efficiency: An application of data envelopment analysis to Chinese enterprises (1986-1990). Journal of Comparative Economics, 26(3), 465-484. https://doi.org/10.1006/jeec.1998.1540

Zhang, A., Zhang, Y., \& Zhao, R. (2003). A study of the R\&D efficiency and productivity of Chinese firms. Journal of Comparative Economics, 31(3), 444464. https://doi.org/10.1016/S0147-5967(03)00055-6 